\title{
Low back pain in the workplace: attainable benefits not attained
}

It has been just over five years since the Report of the Quebec Task Force on Spinal Disorders in the Workplace was published' but, as often happens, the report has been "without honour in its own land." The Quebec Research Institute on Workers' Health and Safety (Institut de la recherche en santé et securite au travail (IRSST)) diffused the report timidly and late to doctors and other health professionals in the Province. It took until 1989 before a focused and consistent research agenda was adopted by the IRSST or any other Quebec agency to consider the report's conclusions and recommendations, especially those on research priorities. The Quebec Workmens' Compensation Board (Conseil en santé et securité au travail (CSST)) to this day has failed to implement any clinical or organisational recommendations of the task force. It is generally acknowledged that this is largely because of strong opposition by organised labour. The unions never liked the key conclusion of the report: "The best treatment for low back pain without radiation or objective clinical signs is work." The unions (and most health professionals) did not appreciate the distinction between hurt and harm. The task force found that working with pain hurts but does not harm and that failing to return to work because of pain promotes a great deal of harm. A doctors' typical approach at the time to prescribe bed rest for up to two weeks with concurrent sick leave certificates (often renewed more than once) has not changed much. And yet that approach to treatment is probably the main determinant of real harm in disorders of the vertebral column-namely, chronicity. A subgroup of the task force demarcated the entire cohort of workers affected in 1981 and followed them up for four years. To my astonishment as chairman of the task force (and contrary to my a priori convictions) the research and statistics subgroup, led by Abenhaim and Suissa, found that $70 \%$ of the 150 million Canadian dollars expended annually on problems related to low back pain by the CSST were attributable to only $7 \%$ of the affected workers. ${ }^{2}$ Who were those workers? Those who had become chronic that is, were off work for six months or more. Follow up of the trajectory of those with chronic disability or chronic pain syndrome strongly suggests that such outcomes are aided and abetted by the health care provision system in general and by doctors and physiotherapists in particular. Much responsibility for chronicity rests in the lap of employers. Characteristically employers will not take the workers back until they are "completely well", which usually means free of any pain. Ironically, the villains in promoting chronicity are not the workers, nor the unions, but the health professions, the health system including the CSST, and the employers.

Sadly, another key set of findings of the task force clearly showed that most of what is done with low back pain and other spinal disorders in terms of treatment and rehabilitation is not justified by scientifically admissible evidence of its effectiveness. That, also, is not the fault of the workers but of the scientific and medical communities. The proliferation of diagnostic and therapeutic interventions for low back pain in the past 20 years is such that it will take more than a few trials and nonexperimental studies to convince clinicians to stop doing what has been shown to be useless or has never been shown to be effective. For instance, it took 25 years to incorporate the notion into mainstream medical practice that pre-employment $x$ ray films of the spine to screen out high risk workers is ineffectual and that they should not be done for that purpose. ${ }^{3}$

The task force found, early in its deliberations, that an important obstacle to progress in clinical research on disorders of the vertebral column was the lack of a consistent and meaningful taxonomy for symptoms, signs, diagnoses, and treatments. One of the first goals accomplished was to standardise the pertinent clinical, physiological, anatomical, pathological, and therapeutic terminology in a way that made scientific sense and common sense. Some of the task force conclusions that ruffled feathers among players in the low back pain arena were that:

A clinical history and physical examination are usually sufficient to identify most patients for whom a specific treatment is required.

Diagnostic radiological studies of the spine are of 
limited value in the primary evaluation of most activity related spinal disorders.

There is no need for obligatory bed rest in low back pain in the absence of important radiation. When it is prescribed it should not usually continue for more than two days ... prolonged bed rest can have adverse effects.

Low back pain without anatomical disorder objectively shown is not an indication for spinal surgery.

Surgery is indicated in the treatment of activity related disorders only after conservative treatments have failed (major trauma excluded).

A second surgical intervention is indicated only in exceptional circumstances.

Even if there is residual chronic pain, return to work is not contraindicated. Work may be therapeutic ...

To reach conclusions such as the foregoing, the Quebec task force limited itself strictly to evidence, not opinion even though internationally known experts were part of the group. Whether the opinions were based on empirical standards of usual care or the prescribed normative standards of experts we did not accept them without evidence to back them. Moreover, the evidence had to be scientifically admissible by pre-determined criteria for it to be incorporated in our decision making process.

How did we bring evidence to bear? A unique method, refined in the work of the Quebec task force, but introduced in the work of some of our earlier task forces, is the distinctive way we selected and invoked information from the world publications. The method, known as Best Evidence Synthesis was pioneered by Slavin in educational research and we adapted it to the biomedical field. ${ }^{4}$ The method goes much beyond a haphazard review of published work but eschews the confining rigidities of conventional meta-analysis. As in metaanalysis, it requires predetermined ground rules on the scientific admissibility of published papers and on the internal and external validity of findings distilled from original articles. Only then is such evidence invoked in a synthesis focused on a particular question, a clinical intervention, a diagnostic test, or a rehabilitative programme. Both meta-analysis and best evidence synthesis are highly vulnerable to publication bias-that is, the systematically greater difficulty in searching and locating unpublished studies with negative findings. Both approaches emphasise numerical findings but unlike metaanalysis, best evidence syntheses need not depend on a single estimate of effect or even on statistical significance. ${ }^{5}$

Having gone through the exhaustive process summarised above, and having reviewed over 7000 original reports of research, various tables in the report highlight the huge gaps in evidence about most interventions for low back pain at any stage. The deficits apply nearly equally to the treatments and diagnoses of surgeons, physicians, general practitioners, physiotherapists, physiatrists, and psychiatrists. The evidence is no worse and no better for the manoeuvres of chiropractors or osteopaths.

Recommendations on research priorities were easy because of the gaps found. Virtually nothing is known about primary prevention. Ergonomists may be on the right track but so far have little to show about effectiveness among representative workers in properly designed follow up studies. Tertiary prevention holds much promise but there is much resistance to fund trials evaluating the expensive treatment programmes that seek to prevent chronicity or to rehabilitate low back pain patients with chronic disability. The huge direct and indirect costs of low back pain to society and individual patients warrant the utmost rigour in such trials. Their complexity and the necessary sample sizes require large budgets to do the investigations properly but, industry and the funding agencies are reluctant to invest in multimillion dollar research projects. It no longer surprises me how easily one forgets the price of poor research or of lack of evidence. I estimate that as much as $10 \%$ of the total Workmens' Compensation expenditures in any Canadian province (more than $\$ 10000000$ per year per million inhabitants) is spent on unnecessary sick leave and ineffective treatments for low back pain alone. I do not even include indirect or opportunity costs. Much of such waste is avoidable with new data generated by research of admissible standards and if workers, employers, and clinicians will appreciate that the myths of the past must be set aside without delay.

As a Quebecker, I am not unduly discouraged by the reluctance seen in my province to accept the Report of the Quebec Task Force on Spinal Disorders in the Workplace. It has often been cited in much of the developed world, ${ }^{6-25}$ notably in the United States. ${ }^{70-1623-25}$ The Scandinavians are probably at the forefront, implementing the research priorities and evaluating the strategies that are basically consistent with what we formulated and recommended with thoughtful policies and good studies. ${ }^{212226-39}$ Other countries have contributed studies as well. ${ }^{40-49}$ As is so often true in Canada for sports stars, for scientific forerunners, for inventors, and for the celebrities in the arts, once it is seen that what has been created at home is accepted south of the border, the new "product" is then embraced and espoused.

What messages from the Quebec Task Force on Spinal Disorders at the Workplace should be retained and assertively diffused? The following five, in my view: 
(1) workers with symptoms of low back pain, particularly first time casualties, should be strongly urged to return to work almost immediately if there are no objective signs found by the clinician who only needs a good history and physical examination to classify the type of problem and decide on its management.

(2) Pain alone is an insufficient cause to delay resumption of work.

(3) The few patients failing to respond to conservative management should be followed up aggressively with standardised diagnostic packages and forceful treatment programmes that minimise absenteeism.

(4) Our current health system and employers' attitudes, encourage a drift towards six months of sick leave for workers with stubborn low back pain should have its strategies radically altered to prevent chronicity.

(5) Almost everything we do as clinicians for patients with low back pain needs to be evaluated, or to be re-evaluated, or confirmed with well designed and properly executed randomised controlled trials or observational non-experimental studies. The study subjects should be patients and the priority outcome should be return to work.

The hurt of low back pain is not necessarily harmful; chronicity is harmful and can be devastating to the workers and or their families. We do not have sufficient knowledge to prevent the occurrence of new low back pain. We probably can prevent most chronic disability that is back related. Indeed, there are attainable benefits not attained for workers that can be realised by exerting political will and some courage on the part of all stakeholders in this difficult endeavour of health promotion in the workplace.

Department of Epidemiology and Biostatistics,

WALTER O SPITZER

McGill University, Faculty of Medicine,

Purvis Hall, 1020 Pine Avenue West, Montreal,

Quebec, Canada H3A $1 A 2$

1 Spitzer WO, LeBlanc FE, Dupuis M, et al. Scientific approach to the assessment and management of activity-related spinal disorders. A monograph for clinicians. Report of the Quebec Task Force on Spinal Disorders. Spine 1987;12:S4-S59.

2 Abenhaim LL, Suissa S. Importance of economic burden of occupational back pain: A study of 2500 cases representative of Quebec. F Occup Med 1987;22:670-4.

3 Gibson E. The value of preplacement screening radiography of the low back. State Art Rev Occup Med 1988;3:91-107.

4 Slavin RE. Best-evidence synthesis: an alternative to metaanalytic and traditional reviews. Educ Res 1986;15:5-11.

5 Spitzer WO. Meta-meta-analysis: unanswered questions about aggregating data. $\mathcal{F}$ Clin Epidemiol 1991;44:103-7.

6 Badley E. The impact of musculoskeletal disorders on the Canadian population. F Rheumatol 1992;19:337-40.

7 Battie MC, Bigos SJ. Industrial back pain complaints. A broader perspective. Orthop Clin North Am 1991;22:273-82.

8 Coste J, Paolaggi JB, Spira A. Classification of nonspecific low back pain. I. Psychological involvement in low back pain. A clinical descriptive approach. Spine 1992;17:1028-37.

9 Coste J, Paolaggi JB, Spira A. Classification of nonspecific low back pain. II. Clinical diversity of organic forms. Spine 1992;17:1038-42.

10 DeRosa CP, Porterfield JA. A physical therapy model for the treatment of low back pain. Phys Ther 1992;72:261-72.

11 Deyo RA. Plain roentgenography for low back pain. Finding needles in a haystack. Arch Intern Med 1989;149:27-9.

12 Deyo RA, Bigos SJ, Maravilla RR. Diagnostic imaging procedures for the lumbar spine. Ann Intern Med 1989;111:865-7.

13 Deyo RA, Loeser JD, Bigos SJ. Herniated lumbar interbral disk. Ann Intern Med 1990;112:598-603.

14 Federspiel CF, Guy D, Kane D, Spengler D. Expenditures for nonspecific back injuries in the workplace. $\mathrm{F}$ Occup Med 1989;31:919-24.

15 Frymoyer JW. Predicting disability from low back pain. Clin Orthop 1992;279:101-9.

16 Haig AJ, Penha S. Rehabilitation medicine-adding life to years. West $\mathcal{F}$ Med 1991;154:528-31.

17 Helliwell PS. Occupational rheumatology: are we using the wrong model? Br f Rheumatol 1992;31:73-6.

18 Koes BW, Assendelft WJJ, van der Heijden GJMG, Bouter LM, Knipschild PG. Spinal manipulation and mobilisation for back and neck pain: a blinded review. BMF 1991; 303:1298-303.

19 Koes BW, Bouter LM, Beckerman H, van der Heijden GJMG, Knipschild PG. Physiotherapy exercises and back pain: a blinded review. BMF 1991;302:1572-6.

20 Koes BW, Bouter LM, van Mameren H, et al. Randomised clinical trial of manipulative therapy and physiotherapy for persistent back and neck complaints: results of one year follow up. BMJ 1992;304:601-5.

21 Lindstrom I, Ohlund C, Eek C, et al. The effect of graded activity on patients with subacute low back pain: a randomized prospective clinical study with an operant-conditioning behavioural approach. Phys Ther 1992;72:279-93.

22 Makela $M$, Hellovaara $M$, Sievers $K$, Impivaara $O$, Knekt $P$, Aromaa A. Prevalence, determinants, and consequences of chronic neck pain in Finland. Am $\mathcal{F}$ Epidemiol 1991; 134:1356-67.

23 Rudy TE, Turk DC, Brena SF, Stieg RL, Brody MC. Quantification of biomedical findings of chronic pain patients: development of an index of pathology. Pain 1990; 42:167-82.

24 Tenhaula JA, Rose SJ, Deletto A. Association between direction of lateral lumbar shift movement tests and site of symptoms in patients with low back pain syndrome. Phys Ther 1990;70:480-6.

25 Von Korff M, Dworkin SF, Le Resche L. Graded chronic pain status: an epidemiologic evaluation. Pain 1990;40:279-91.

26 Holmström E, Moritz U. Low back pain-correspondence between questionnaire interview and clinical examination. Scand F Rehab Med 1991;23:119-25.

27 Holmström E, Moritz U, Anderson M. Trunk muscle strength and back muscle endurance in construction workers with and without low back disorders. Scand f Rehabil Med 1992;24:3-10.

28 Lindström I, Ohlund C, Eek C, Wallin L, Peterson LA, Nachemson A. Mobility, strength, and fitness after a graded activity program for patients with subacute low back pain. A randomized prospective clinical study with a behavioural therapy approach. Spine 1992;17:641-52.

29 Stankovic R, Johnell O. Conservative treatment of acute lowback pain. A prospective randomized trial: McKenzie method versus patient education in "mini back school". Spine 1990;15:120-3.

30 Estlander A, Mellin G, Vanharanta H, Hupli M. Effects and follow-up of a multimodel treatment program including intensive physical training for low back pain patients. Scand f Rehabil Med 1991;23:97-102.

31 Härkäpää K, Järvikoski A, Mellin G, Hurri H. A controlled study on the outcome of inpatient and outpatient treatment of low back pain. Part I. Pain, disability, compliance, and reported treatment benefits three months after treatment. Scand F Rehabil Med 1989;21:81-9.

32 Hurri $\mathrm{H}$. The Swedish back school in chronic low back pain. Part I. Benefits. Scand F Rehabil Med 1989;21:33-40.

33 Hurri $\mathrm{H}$. The Swedish back school in chronic low back pain, II. Part II. Factors predicting the outcome. Scand $\mathcal{F}$ Rehabil Med 1989;21:41-4.

34 Mellin G, Hurri H, Härkäpää K, Järvikoski A. A controlled study on the outcome of inpatient and outpatient treatment 
of low back pain. Part II. Effects on physical measurements three months after treatment. Scand $\mathcal{F}$ Rehabil Med 1989: 21:91-5.

35 Talo S, Rytökoski U, Puukka P. 1992 Volvo award in clinical sciences. Patient classification, a key to evaluate pain treatment: a psychological study in chronic low back pain patients. Spine 1992;17:998-1011.

36 Oland $G$, Tveiten $G$. A trial of modern rehabilitation for chronic low-back pain and disability. Vocational outcome and effect of pain modulation.

37 Westgaard RH, Jansen T. Individual and work related factors associated with symptoms of musculoskeletal complaints. I A quantitative registration system. Br f Ind Med 1992; 49:147-53.

38 Westgaard RH, Jansen $T$. Individual and work related factors associated with symptoms of musculoskeletal complaints. II Different risk factors among sewing machine operators. $\mathrm{Br} \mathcal{F}$ Ind Med 1992;49:154-62.

39 Biering-Sprensen CE, Thomsen CE, Hilden J. Risk indicators for low back trouble. Scand $\mathcal{F}$ Rehabil Med 1989;21:151-7.

40 Koes BW, Bouter LM, van Mameren H., et al. The effectiveness of manual therapy, physiotherapy, and treatment by the general practitioner for nonspecific back and neck complaints. A randomized clinical trial. Spine 1992;17:28-35.

41 Versloot JM, Rozeman A, van Son AM, van Akkerveeken PF. The cost-effectiveness of a back school program in industry.
A longitudinal controlled field study. Spine 1992;17:22-7.

42 Cherkin D, Deyo RA, Berg AO, Bergman JJ, Lishner DM. Evaluation of a physician education intervention to improve primary care for low-back pain I. Impact on physicians. Spine 1991;16:1168-72.

43 Cherkin D, Deyo RA, Berg f.O. Evaluation of a physician education intervention to improve primary care for low-back pain II. Impact on patients. Spine 1991;16:1173-84.

44 Khalil TM, Asfour SS, Martinez LM, et al. Stretching in the rehabilitation of low-back pain patients. Spine 1992;17: 311-7.

45 Kohles S, Barnes D, Gatchel RJ, Mayer TG. Improved physical performance outcomes after functional restoration treatment in patients with chronic low-back pain. Early versus recent training results. Spine 1990;15:1321-4.

46 Rainville J, Ahern DK, Phalen L, Childs LA, Sutherland R. The association of pain with physical activities in chronic low back pain. Spine 1992;17:1060-70.

47 Mithcell RI, Carmen GM. Results of a multicenter trial using an intensive active exercise program for the treatment of acute soft tissue and back injuries. Spine 1990;15:514-21.

48 Donchin M, Woolf O, Kaplan L, Floman Y. Secondary prevention of low-back pain. A clinical trial. Spine 1990; 15:1317-20.

49 Greenough CG, Fraser RD. Assessment of outcome in patients with low-back pain. Spine 1992;17:36-41. 